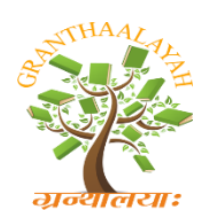

$$
\begin{gathered}
\text { INTERNATIONAL JOURNAL OF RESEARCH - } \\
\text { GRANTHAALAYAH } \\
\text { A knowledge Repository }
\end{gathered}
$$

Science

\title{
HEMATOLOGIC PROFILE OF LABORATORY RATS FED WITH BAKERY PRODUCTS
}

\author{
Muhamed Katica ${ }^{1}$, Nedzad Gradascevic ${ }^{2}$ \\ ${ }^{1}$ Department of Pathological Physiology of Domestic Animals, Veterinary Faculty, University of \\ Sarajevo, Bosnia and Herzegovina \\ ${ }^{2}$ Department of Radiobiology with Radiation Hygiene, Biophysics and Environmental \\ Protection, Veterinary Faculty, University of Sarajevo, Bosnia and Herzegovina
}

DOI: https://doi.org/10.29121/granthaalayah.v5.i5.2017.1853

\begin{abstract}
The laboratory rat, as important biomedical model, was often fed with unconventional diet usually made up of products from the bakery industry. Such diet consisted of insufficient caloric and nutritionally unbalanced meals could cause unreliable results in biomedical research. The study investigates the effects of malnutrition on the haematological profile of rats.

The study is performed on Wistar male and female rats which were fed for 4 weeks exclusively with bakery products ad libidum. The following hematological parameters were observed in peripheral blood smears: red blood cell count, content of haemoglobin, haematocrit, MCV, $\mathrm{MCH}, \mathrm{MCHC}$, white blood cell count, differential blood count, diameter of red blood cells, as well as the presence of atypical forms of red blood cells.

Despite there were no statistically significant differences in overall haematological results $(\mathrm{p}>$ 0.05 , with > 0.05), the significant part of obtained results were below physiological limits (HGB, $\mathrm{MCHC}$ and $\mathrm{MCH}$ ). Other haematological parameters, including white blood corpuscles were kept in physiological limits, except for mild neutrophils in males. Also, the forms of anulocytes and spherocytes were recorded in peripheral blood smears.

The results indicated the beginning of normocytic hypochromic anaemia which was caused by unbalanced meals.
\end{abstract}

Keywords: Lab Rat; Peripheral Blood Smear; Bakery Products; Malnutrition; Hypochromic Anaemia.

Cite This Article: Muhamed Katica, and Nedzad Gradascevic. (2017). "HEMATOLOGIC PROFILE OF LABORATORY RATS FED WITH BAKERY PRODUCTS." International Journal of Research - Granthaalayah, 5(5), 221-231.https:// doi.org/10.29121/granthaalayah.v5.i5.2017.1853. 


\section{Introduction}

White laboratory rat (Ratus norvegicus) is bred under strictly controlled conditions for years, with no migration of genes, and it has been used in experiments for more than one hundred years. Ratus norvegicus and the laboratory mouse made $85 \%$ of the total number of animals used in research. They are an important experimental model in biological research in the context of fundamental science, research, development and determining the quality of products and devices used in human and veterinary medicine, dentistry and toxicological analyses, as well as in assessing the harmfulness of certain chemicals used in households, industry, agriculture and other safety evaluations.

The laboratory rat is particularly suitable for biomedical research related to cardiovascular diseases, metabolic and neurological disorders, neurobehavioral studies, organ transplants, autoimmune and renal diseases, to study the susceptibility to cancer, as well as the impact of different doses of radioactivity to tissues and haematological parameters. ${ }^{(1-3)}$

It is believed that physiological processes in rats are similar to those of humans, as opposed to the physiological processes in the mice ${ }^{(4)}$. Rats are opportunistic omnivores and have a tendency towards high protein and caloric food. ${ }^{(4-7)}$

A balanced diet is very important for normal growth and development of puerperal rats, but also essential for the good health of adults. Studies on animals have shown the great importance of nutrition during pregnancy and lactation for overall survival, growth and behaviour of offspring. For example, malnutrition of mature females during pregnancy leads to a condition that is usually associated with reduced fetal growth, as well as with reduced body mass of the female alone and the weight of their placenta. ${ }^{(8)}$

Vivarium which breed laboratory animals in accordance with the Law on Protection and Welfare of Animals of Bosnia and Herzegovina use pelleted food in the diet of rats, which implies pressed balanced compound food. One rat eats on average 5 grams of food and drinks $10-20 \mathrm{ml}$ of water per 100 grams of body weight, per day. ${ }^{(9)}$ Food for rats should contain $20-25 \%$ protein, $4 \%$ fat. ${ }^{(10,11)}$

Nutritional deficiency (of zinc, vitamin B2, niacin, biotin) in the meals of rats causes the appearance of unkempt fainter hair, disseminated alopecia and Norwegian dermatitis. ${ }^{(12,13)}$

Scientific studies ${ }^{(14,15)}$ in rats which were fed with white bread and bread enriched with iron and folic acid, suggested an important role of iron and folic acid in the prevention of anaemic conditions and improvement in the immune status of rats.

There are many research centres in third countries which breed laboratory animals in vivarium and are operating with insufficient financial resources. For that reason, they often forced to apply unconventional diet, comprised of nutritionally unbalanced and low caloric meals. In such circumstances, commonly used products in the diet of laboratory rats are those of the bakery industry: dried bread, rolls, pasta and other confectionery products. It is expected that this kind of 
diet, over longer periods of time, adversely affects the general health of the rats as potential experimental animals.

By processing wheat, refined wheat flour is obtained, which is the main ingredient of bread, rolls, pasta and other confectionery products. Numerical values of nutrients from wheat and wheat flour in Table 1 may serve as approximate indicators, as the milling and baking processing of wheat grain result in refined wheat flour whose nutritional value is somewhat different from the value of wheat grain. ${ }^{(16,17)}$

For a good scientific research laboratory animals are essential, including rats of good quality and a thoroughbred breeding, because otherwise any work with animals or their organs could give unreliable results. ${ }^{(11)}$

The aim of the research is to show possible variations of haematological parameters if the lab rats are fed with products from the baking industry over a longer period of time, and to draw attention to researchers that such animals which are fed in this way, should not be chosen for the experiment. Results of the study represented the product of the practical work with laboratory rats and they were not obtained as a result of the specific targeted experiment.

\section{Materials and Methods}

The experiment used twenty four clinically healthy Wistar rats, aged 12-13 weeks, with body weight of 280-300 grams. Rats had free access to food and water during the experiment and a 12hour shift of light and darkness. The air temperature ranged from $20-23^{\circ} \mathrm{C}$, while humidity was kept around $60 \% \pm 10 \%$. They were divided into two groups, control and experimental, with six males and six adult non gravid females, each. During the experiment, which lasted for four weeks, experimental groups were fed with only dried bread, pastries, pasta and other domestic confectionery products. Water was consumed ad libitum. The control groups were fed ad libidum by complete feed for rats with balanced nutritive components.

After four-week diet which consisted of bakery products, blood samples were taken by puncture of the tail vein in EDTA vacutainers. Immediately after sampling, the values of the number of red blood cells, white cells, haemoglobin, blood smears were made in order to analyse the differential blood count $(\%)$, determine the diameter of erythrocytes $(\mu)$, and estimate the presence of poikilocytosis forms of blood corpuscle (\%). Poikilocytosis was classified semiquantitative according to similar research, following the criteria: non-existing $(0 \%)$, rare $(0.05-0.5 \%)$, mild $(>0.5-3 \%)$, modest $(>3-10 \%)$, or expressed $(>10 \%)$. The number and type of poikilocytes was written in percentages of red blood cells. ${ }^{(18)}$ Following the blood smears which were stained by Giemsa method, white blood cells were differentiated and numerical values expressed in percentages after having analysed 1,000 such cells. Binocular microscope (Boeko, Germany) was used in experiment with magnification of 1000 time. In determining the diameter of erythrocytes ocular micrometre was used, and the diameter of 1000 time erythrocytes was determined. The results of the diameter of the red blood cells are not graphically shown, they were only used in assessing the type of anaemia. To estimate haematological parameters of peripheral blood haematological numerator "Idexx Laser Cyte" was used. The parameters that 
had been analysed included: RBC (10 $12 / \mathrm{L}), \mathrm{HGB}(\mathrm{g} / \mathrm{dL}), \mathrm{PCV}(\%), \mathrm{MCV}(\mathrm{fl}), \mathrm{MCH}(\mathrm{pg}) \mathrm{i}$ $\mathrm{MCHC}(\mathrm{g} / \mathrm{dl})$, and WBC $\left(10^{9} / \mathrm{L}\right)$.

A relatively small number of animals were used in this study, when compared to similar studies, according to the ethical principles on the use of laboratory animals for research purposes. ${ }^{(19,20)}$ The results were compared with control groups as well as with physiological reference intervals of Wistar rats aged 12-13 weeks, in order to determine possible differences. The physiological reference intervals were average values from a number of literature sources. ${ }^{(21,22)}$ In the literature sources that describe the physiological variations of haematological parameters in Wistar rats, great ranges between the lower and upper limits of physiological variations exist. Wide ranges of physiological variations can be explained by variation in age, sex, breed or strain, as well as by variation in sampling techniques and methodology of the study.

The values were statistically processed using Excel 2013, and results were compared with literature data. The statistical significance of the results was determined by statistical tests (descriptive statistics, t-test, z-test and Fisher's test).

\section{Results and Discussions}

By daily monitoring of rats who underwent four weeks of the exclusive consumption of bakery products, certain changes were noticed in animals. Following clinical symptoms, although their analysis was not the primary task of this study, were observed: depression, decreased appetite, decreased weight loss, somnolence, pale mucous membranes and coarse hair without shine. These symptoms clearly point to multi-day consumption of food which is insufficient for the needs of rats, diet which fails to provide needed amount of proteins and fats, as well as certain vitamins and minerals (Table 1 and 2). Utilization of nutrients from the baked goods in the body of rat, taking into account its need for energy, building and protective substances, is definitely questionable.

Wheat grain is a good source of iron, but its bioavailability is relatively low. Numerous reports have been published on the average iron content in wheat, which showed that the average iron content is $5 \mathrm{mg}$ per 100 grams of wheat ${ }^{(23)}$, although recent reports indicate that the values are actually between 3 and $4 \mathrm{mg}$ per 100 grams of wheat. ${ }^{(24)}$ It is known that products such as refined flour contain less iron than the whole wheat grain. ${ }^{(24)}$ From the literature data listed in Table 1, it is evident that wheat flour contains iron in the amount of $10.5-54.4 \mathrm{mg} / \mathrm{g}{ }^{(17)}$ which should ultimately serve the needs of rats for iron, which amount to $35 \mathrm{mg} / \mathrm{kg}$ of food. ${ }^{(13)}$ When taking into account the daily food consumption by the rats in an amount of $5 \mathrm{~g}$, the estimated daily intake of iron by rats is between 51.5 - $272 \mathrm{mg}$ of iron a day. However, as haematological parameters obtained in the experiment indicated the beginning of chronic iron deficiency anaemia; it could be concluded that the real needs of the rats for iron are significantly larger than those from literature data and daily intake estimated in this study. The review of the literature data about the nutritional components of the wheat and bakery products are presented in Table 1. Nutritional needs of the adult rat are showed In Table 2. 
Table 1: Part of the nutritional value of wheat (A) and wheat flour (B)

\begin{tabular}{|c|c|c|c|c|c|}
\hline \multicolumn{2}{|c|}{ The main nutrients } & Micro elements & Vitamins & Macro & Source \\
\hline A & $\begin{array}{r}71 \% \\
\text { carbohydrates }\end{array}$ & $\begin{array}{r}\mathrm{Cu} \\
0,5 \mathrm{mg} / 100 \mathrm{~g} \\
\end{array}$ & $\begin{array}{r}\text { folic acid, } \mathrm{B}_{9} \\
26 \mu \mathrm{g} / 100 \mathrm{~g}\end{array}$ & $\begin{array}{r}\mathrm{Mg} \\
144 \mathrm{mg} / 100 \mathrm{~g}\end{array}$ & Rengal et al. 1999 \\
\hline B & $\begin{array}{r}68,5 \% \\
\text { carbohydrates }\end{array}$ & $\begin{array}{r}\mathrm{Cu}: \\
1,84-2,7 \mu \mathrm{g} / \mathrm{g}\end{array}$ & $\begin{array}{r}\text { folic acid, } \mathrm{B}_{9} \\
51 \mu \mathrm{g} / 100 \mathrm{~g}\end{array}$ & $\begin{array}{r}\mathrm{Mg} \\
2,9-4,2 \mu \mathrm{g} / \mathrm{g}\end{array}$ & $\begin{array}{l}\text { Rennan et al. } 2008 \\
\text { Kumar et al. } 2011\end{array}$ \\
\hline A & $\begin{array}{c}13 \% \\
\text { proteins } \\
\end{array}$ & $\begin{array}{r}\mathrm{Fe} \\
3,5 \mathrm{mg} / 100 \mathrm{~g} \\
\end{array}$ & $\begin{array}{l}\text { thiamine, } \mathrm{B}_{1} \\
0,4 \mathrm{mg} / 100 \mathrm{~g}\end{array}$ & $\begin{array}{r}\mathrm{P} \\
508 \mathrm{mg} / 100 \mathrm{~g} \\
\end{array}$ & Rengal et al. 1999 \\
\hline B & $\begin{array}{r}12,6 \% \\
\text { proteins }\end{array}$ & $\begin{array}{r}\mathrm{Fe} \\
10,5-54.4 \mu \mathrm{g} / \mathrm{g} \\
\end{array}$ & $\begin{array}{l}\text { thiamine, } \mathrm{B}_{1} \\
0,3 \mathrm{mg} / 100 \mathrm{~g}\end{array}$ & $\begin{array}{r}\mathrm{P} \\
5,7-8,4 \mu \mathrm{g} / \mathrm{g} \\
\end{array}$ & $\begin{array}{l}\text { Rennan et al. } 2008 \\
\text { Kumar et al. } 2011 \\
\end{array}$ \\
\hline A & $\begin{array}{r}2,5 \% \\
\text { fat }\end{array}$ & $\begin{array}{r}\mathrm{Zn} \\
4 \mathrm{mg} / 100 \mathrm{~g}\end{array}$ & $\begin{array}{r}\text { Niacin, } B_{3} \\
6,7 \mathrm{mg} / 100 \mathrm{~g}\end{array}$ & - & Ozturk et. al., 2006 \\
\hline B & $\begin{array}{r}2,0 \% \\
\text { fat }\end{array}$ & $\begin{array}{r}\mathrm{Zn} \\
6,6-9,4 \mu \mathrm{g} / \mathrm{g} \\
\end{array}$ & $\begin{array}{c}\text { Niacin, } \mathrm{B}_{3} \\
1,7 \mathrm{mg} / 100 \mathrm{~g}\end{array}$ & & $\begin{array}{c}\text { Rennan et al. } 2008 \\
\text { Kumar et al. } 2011\end{array}$ \\
\hline A & & $\begin{array}{r}\mathrm{Mn} \\
3 \mathrm{mg} / 100 \mathrm{~g}\end{array}$ & $\begin{array}{l}\text { riboflavin, } \mathrm{B}_{2} \\
0,72 \mathrm{mg} / 100 \mathrm{~g}\end{array}$ & - & $\begin{array}{l}\text { Ozturk et. al., } 2006 \\
\text { Kumar et al. } 2011\end{array}$ \\
\hline B & & $\begin{array}{r}\mathrm{Mn} \\
5,8-8,2 \mu \mathrm{g} / \mathrm{g} \\
\end{array}$ & $\begin{array}{l}\text { riboflavin, } \mathrm{B}_{2} \\
0,07 \mathrm{mg} / 100 \mathrm{~g}\end{array}$ & & $\begin{array}{c}\text { Rennan et al. } 2008 \\
\text { Kumar et al. } 2011 \\
\end{array}$ \\
\hline $\mathrm{A}$ & & $\begin{array}{r}\text { selenium } \\
89 \mathrm{mg} / 100 \mathrm{~g}\end{array}$ & $\begin{array}{r}\text { pyridoxine, } \mathrm{B}_{6} \\
0,4 \mathrm{mg} / 100 \mathrm{~g}\end{array}$ & - & Rengal et al. 1999 \\
\hline
\end{tabular}

Table 2: Part of the daily nutritional needs of adult rat ( $\mathrm{mg} / \mathrm{kg}$ of food)

\begin{tabular}{|c|c|c|c|c|}
\hline $\begin{array}{l}\text { The main } \\
\text { nutrients }\end{array}$ & Micro elements & Vitamins & $\begin{array}{l}\text { Macro } \\
\text { elements }\end{array}$ & Source \\
\hline $\begin{array}{l}65-70 \% \\
\text { carbohydrates }\end{array}$ & $\begin{array}{l}\text { copper } \\
5 \mathrm{mg} / \mathrm{kg} \text { of food }\end{array}$ & $\begin{array}{l}\text { Folic acid, } \mathrm{B}_{9} \\
1 \mathrm{mg} / \mathrm{kg} \text { of food }\end{array}$ & $\begin{array}{l}\text { magnesium } \\
0,4 \mathrm{~g} / \mathrm{kg} \text { of } \\
\text { food }\end{array}$ & $\begin{array}{l}\text { Mujezinović and } \\
\text { Muminović, 2012. } \\
\text { Muminović et al 2006. }\end{array}$ \\
\hline $20-25 \%$ proteins & $\begin{array}{l}\text { iron } \\
35 \mathrm{mg} / \mathrm{kg} \text { of food }\end{array}$ & $\begin{array}{l}\text { thiamine, } B_{1} \\
4 \mathrm{mg} / \mathrm{kg} \text { of food }\end{array}$ & $\begin{array}{l}\text { phosphorus } \\
4 \mathrm{mg} / \mathrm{kg} \text { of } \\
\text { food }\end{array}$ & $\begin{array}{l}\text { Mujezinović } \\
\text { Muminović, 2012. } \\
\text { Muminović et al.2006. }\end{array}$ \\
\hline $4 \%$ fat & $\begin{array}{l}\text { zinc } \\
12 \mathrm{mg} / \mathrm{kg} \text { of food }\end{array}$ & $\begin{array}{l}\text { niacin, } B_{3} \\
10 \mathrm{mg} / \mathrm{kg} \text { of food }\end{array}$ & - & $\begin{array}{l}\text { Mujezinović } \\
\text { Muminović, } 2012 \text {. } \\
\text { Muminović et al .2006. }\end{array}$ \\
\hline- & $\begin{array}{l}\text { manganese } \\
50 \mathrm{mg} / \mathrm{kg} \text { of food }\end{array}$ & $\begin{array}{l}\text { riboflavin } B_{2} \\
4 \mathrm{mg} / \mathrm{kg} \text { of food }\end{array}$ & - & $\begin{array}{ll}\text { Mujezinović } & \text { and } \\
\text { Muminović, } 2012 & \\
\end{array}$ \\
\hline- & $\begin{array}{l}\text { selenium } \\
0,15 \mathrm{mg} / \mathrm{kg} \text { of } \\
\text { food }\end{array}$ & $\begin{array}{l}\text { pyridoxine, } B_{6} \\
6 \mathrm{mg} / \mathrm{kg} \text { of food }\end{array}$ & - & $\begin{array}{l}\text { Mujezinović } \\
\text { Muminović, } 2012\end{array}$ \\
\hline
\end{tabular}

In earlier work, it was noted that the body of the rats in the initial phase of experimental studies compensated for the insufficient intake of iron by using it from aging red blood cells through the cells of the monocyte-macrophage system, from where it was transported to the bone marrow, where the erythroblasts then re-used it for the synthesis of haemoglobin. ${ }^{(25,26)}$ Generally, decreased haemoglobin levels indicate anaemia. ${ }^{(27)}$ Insufficient intake of iron per os is most common in young categories in the early puerperium. ${ }^{(13,25)}$ Taking into account the high physiological variations of haematological parameters, applied statistical tests did not register statistically significant differences of total scores ( $p>0.05$, with>0.05). However, reduced haemoglobin values were detected in the blood of adults in both experimental groups, relative to 
the lower boundary of Wistar rats. (Graph. 1). Also, slightly lower values were found in females when compared to males. Number of red blood cells remained in the lower physiological range in both groups. Microscopic analysis of the diameter of red blood cells showed that the diameter of the red blood cells was not going beyond the reference physiological framework in any of the groups, but it gravitated towards the upper physiological limit.

Table 3: Haematological parameters of males $(n=6)$

\begin{tabular}{|c|c|c|c|c|c|}
\hline Parameter & Group & Min & $\operatorname{Max}$ & Mean & SD \\
\hline \multirow[t]{2}{*}{ PCV (\%) } & control & 41 & 47 & 45 & 1,63 \\
\hline & experiment & 42 & 60 & 51.6 & 6.53 \\
\hline \multirow[t]{2}{*}{ HGB (g/L) } & control & 133 & 155 & 149.8 & 9.98 \\
\hline & experiment & 125 & 145 & 129,3 & 7.91 \\
\hline \multirow[t]{2}{*}{$\mathrm{RBC}\left(10^{12} / \mathrm{L}\right)$} & control & 7.7 & 9.2 & 8.5 & 0.64 \\
\hline & experiment & 8.3 & 11.5 & 9.1 & 1.21 \\
\hline \multirow[t]{2}{*}{$\mathrm{WBC}\left(10^{9} / \mathrm{L}\right)$} & control & 6.6 & 11.3 & 8.6 & 2.0 \\
\hline & experiment & 3.5 & 10 & 6.9 & 2.57 \\
\hline \multirow[t]{2}{*}{$\mathrm{MCH}(\mathrm{pg}))$} & control & 15.7 & 18.2 & 17.4 & 0.92 \\
\hline & experiment & 11.1 & 16.2 & 14.4 & 1.80 \\
\hline \multirow[t]{2}{*}{$\mathrm{MCHC}(\%)$} & control & 30 & 33 & 31.7 & 1.50 \\
\hline & experiment & 21 & 29 & 24.8 & 2.99 \\
\hline \multirow[t]{2}{*}{$\mathrm{MCV}(\mathrm{fl})$} & control & 50 & 54.1 & 52.5 & 1.51 \\
\hline & experiment & 41 & 71 & 57.9 & 11.7 \\
\hline \multirow[t]{2}{*}{ Lymphocytes (\%) } & control & 65 & 89.2 & 77.2 & 8.92 \\
\hline & experiment & 65 & 77 & 70.5 & 4.32 \\
\hline \multirow[t]{2}{*}{ Monocytes (\%) } & control & 1 & 4 & 1.9 & 1.11 \\
\hline & experiment & 0 & 3,5 & 1.3 & 1.17 \\
\hline \multirow[t]{2}{*}{ Neutrophils (\%) } & control & 9 & 23 & 17.7 & 5.92 \\
\hline & experiment & 22.4 & 43.4 & 32.5 & 8.56 \\
\hline \multirow[t]{2}{*}{ Eosinophils (\%) } & control & 0 & 3 & 1.4 & 1.11 \\
\hline & experiment & 0 & 1.2 & 0.3 & 0.46 \\
\hline \multirow[t]{2}{*}{ Basophils (\%) } & control & 0 & 0.5 & 0.1 & 0.20 \\
\hline & experiment & 0 & 0.2 & 0.06 & 0.10 \\
\hline
\end{tabular}

Menkinoska and Gjorgoski (14) noticed the compatibility of the results related to the haemoglobin, while the results for the total number of red blood cells were different. In the same survey erythropenia was recorded in the peripheral blood at Wistar rats who were fed with white bread for three weeks. In the second group of rats who were fed with bread enriched with iron doses $(60 \mathrm{mg} / \mathrm{kg}$ ) and folic acid (1.6 mg / kg), polycythaemia and hypochromia were recorded. This finding indicates the importance of iron intake per os, in terms of enhanced erythropoiesis in the bone marrow.

Test results of haemoglobin concentration in red blood cells (MCHC), as well as the $\mathrm{MCH}$ values were lower than the lower physiological limit, in both experimental groups (Table 3 , Table 4 and Graph. 1), although a statistically significant difference was not recorded. Volume of red blood cells MCV was increased in both experimental groups, and it was higher in females. Haematocrit value was kept within the reference interval, although the derived values gravitated towards the upper physiological limit (Table 3 and 4), which was not in accordance with the results of some other research. ${ }^{(14)}$ 
Table 4: Haematological parameters of females $(n=6)$

\begin{tabular}{|c|c|c|c|c|c|}
\hline Parameter & Group & Min & Max & Mean & $\mathrm{SD}$ \\
\hline \multirow{2}{*}{$\mathrm{PCV}(\%)$} & control & 42 & 49 & 44,9 & 1.83 \\
\hline & experiment & 39 & 54 & 47 & 5.47 \\
\hline \multirow[t]{2}{*}{ HGB (g/L) } & control & 128 & 162 & 148.3 & 14.5 \\
\hline & experiment & 105 & 124 & 110.5 & 7.81 \\
\hline \multirow[t]{2}{*}{$\mathrm{RBC}\left(10^{12} / \mathrm{L}\right)$} & control & 8.1 & 10.1 & 8.8 & 0.69 \\
\hline & experiment & 7.7 & 8.9 & 8.13 & 0.41 \\
\hline \multirow[t]{2}{*}{ WBC $\left(10^{9} / \mathrm{L}\right)$} & control & 6.4 & 9.7 & 7.8 & 1.23 \\
\hline & experiment & 4.4 & 13.3 & 7.73 & 3.40 \\
\hline \multirow[t]{2}{*}{$\mathrm{MCH}(\mathrm{pg}))$} & control & 16.2 & 19.2 & 17.2 & 1.20 \\
\hline & experiment & 13 & 15.1 & 13.7 & 0.80 \\
\hline \multirow[t]{2}{*}{$\mathrm{MCHC}(\%)$} & control & 29 & 35 & 31.7 & 2.42 \\
\hline & experiment & 21.4 & 26.9 & 23.9 & 2.23 \\
\hline \multirow[t]{2}{*}{ MCV (fl) } & control & 49.2 & 55.5 & 52.1 & 2.32 \\
\hline & experiment & 48.8 & 66.6 & 57.7 & 7.22 \\
\hline \multirow[t]{2}{*}{ Lymphocytes (\%) } & control & 70 & 83 & 75.5 & 4.93 \\
\hline & experiment & 65.5 & 80 & 72.1 & 8.83 \\
\hline \multirow[t]{2}{*}{ Monocytes (\%) } & control & 1.5 & 3 & 2.33 & 075 \\
\hline & experiment & 1.4 & 3.6 & 2.5 & 0.92 \\
\hline \multirow[t]{2}{*}{ Neutrophils (\%) } & control & 14.5 & 25 & 17.7 & 3.71 \\
\hline & experiment & 18.2 & 41 & 24.9 & 8.34 \\
\hline \multirow[t]{2}{*}{ Eosinophils (\%) } & control & 0 & 1 & 0.6 & 0.49 \\
\hline & experiment & 0 & 1.4 & 0.4 & 0.54 \\
\hline \multirow[t]{2}{*}{ Basophils (\%) } & control & 0 & 1 & 0.7 & 0.41 \\
\hline & experiment & 0 & 0.2 & 0.07 & 0.10 \\
\hline
\end{tabular}

Copper is essential for the homeostasis of the iron in rats, i.e. for its utilization in terms of its installation in haemoglobin ${ }^{(13,25)}$. In rats, the daily requirement for copper is $5 \mathrm{mg} / \mathrm{kg}$ of food (Table 2). In refined wheat flour, and in the finished baked goods, copper is present at a concentration of $1-2.8 \mathrm{~g} / \mathrm{g},{ }^{(17)}$ what results in reduced intake of copper in an amount of 1-2.8 $\mathrm{mg} / \mathrm{kg}$ of food. Estimated daily intake of copper in rats used in the study amounted to $9.2-13.5$ mg. Because the experimental animals were consuming such food with low levels of copper, it can be assumed that the said deficit contributed to appearance of hypochromic anaemia.

Daily requirement for folic acid for rats is $1 \mathrm{mg} / \mathrm{kg}$ food (Table 2), while its presence in the bakery products from wheat flour is very low $(51 \mathrm{mg} / 100 \mathrm{~g}$ - Table 1). Daily intake of food of rats in amount of 5 grams, gave the estimated daily intake of folic acid of $2.55 \mu \mathrm{g}$ per meal of rats used in the experiment, and $0.51 \mathrm{mg} / \mathrm{kg}$ of food. Such a low intake of folic acid, with previously considered iron deficiency, was most likely the cause of hypochromic anaemia in rats used in the experiment. In general, folic acid deficiency in animals is manifested by blood disorders in the form of hypochromic anaemia and leukopenia. ${ }^{(13)}$ 


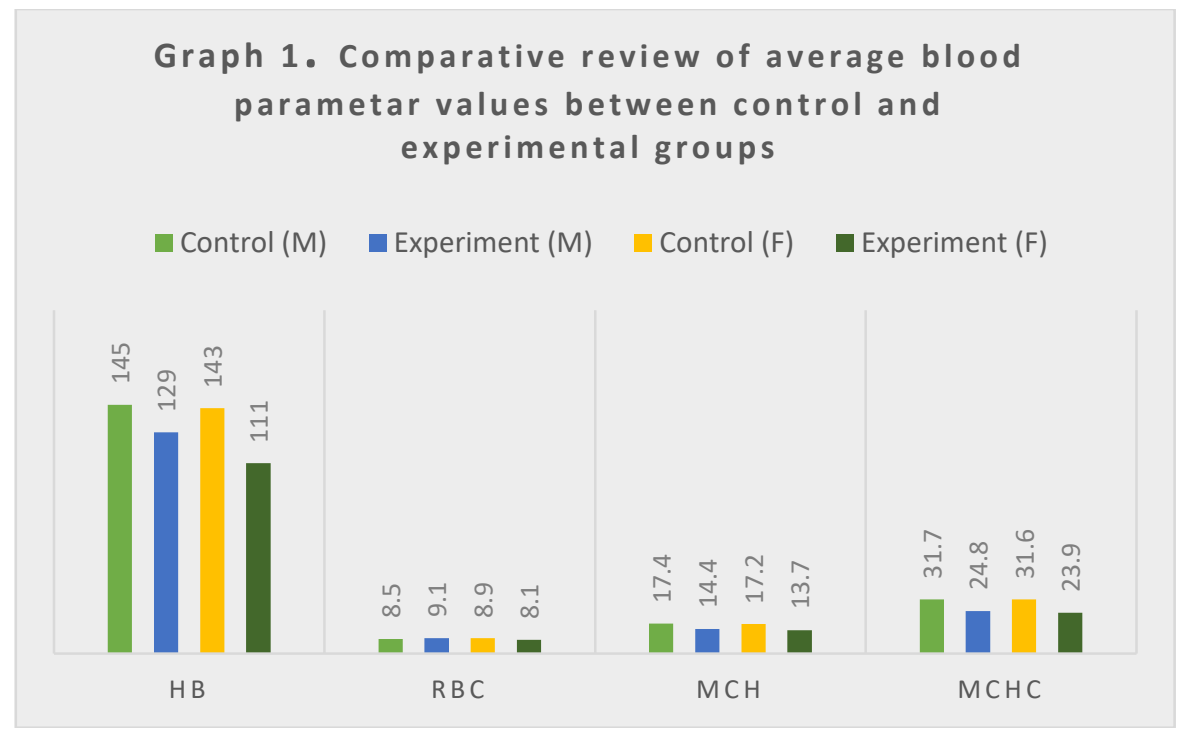

The deficit of vitamin B2 (riboflavin) in rat's meals, in addition to dermatitis, alopecia, cataracts, disturbances in growth and development, leads to anaemia. ${ }^{(13)}$ The daily need for vitamin B2 for rats is $4 \mathrm{mg} / \mathrm{kg}$ of food. ${ }^{(12)}$ Presence of vitamin B2 in wheat flour is very low $(0.07 \mathrm{mg} / 100 \mathrm{~g}$ Table 1), which, on $1 \mathrm{~kg}$ of meal consisting of baked goods made from white flour, amounted to $0.7 \mathrm{mg} / \mathrm{kg}$. It could be assumed that explained deficit of vitamin B2 for four weeks of the experiments on rats also significantly contributed to the occurrence of sideropenic hypochromic anaemia.

According to other authors ${ }^{(28)}$ Vitamin B1 (thiamine) in wheat flour is present at a concentration of $0.3 \mathrm{mg} / 100$ grams of wheat flour, while the daily needs of rats for vitamin B1 amount to 4 $\mathrm{mg} / \mathrm{kg}$ of food. ${ }^{(13)}$ Based on the above, it could be concluded that experimental animals consumed vitamin B1, but not in sufficient quantity. Also, it could be assumed that the partial deficiency of vitamin B1 could cause anorexia, decreased number of red blood cells, white cells, haemoglobin and certain disturbances at the level of the CNS and PNS. ${ }^{(13)}$ However, analysis of obtained results showed that a slight deficit of vitamin $\mathrm{B}_{1}$ in the diet of rats, did not cause oligocythemia, leukopenia and other symptoms that are described in the literature.

By analysing the erythrocyte parameters, it can be concluded that inadequate nutrition of rats in the experiment, which consisted of bakery products, caused the start of sideropenic hypochromic normocytic anaemia. Microscopy of peripheral blood smears of rats showed that the diameter of erythrocytes did not go outside the physiological framework, but obtained values gravitated towards the upper physiological limit. Poikilocytosis forms of red blood cells - anulocytes (5\%) and spherocytes $(3 \%)$ were determined. Incidence of poikilocytosis forms was equal among males and females (anulocytes 5\% and spherocytes $3 \%$ ), which was indicated that incidence of mentioned red blood forms was not influenced by sex. Recorded percentages belonged to mild to modest levels according to semiquantitative classification ${ }^{(18)}$ of poikilocytosis incidence (Fig. 1 A,B and D). Their presence indicated the occurrence of hypochromia. ${ }^{(25,29,30)}$ The presence of mentioned forms was not recorded in control groups (Fig. 1 C). 


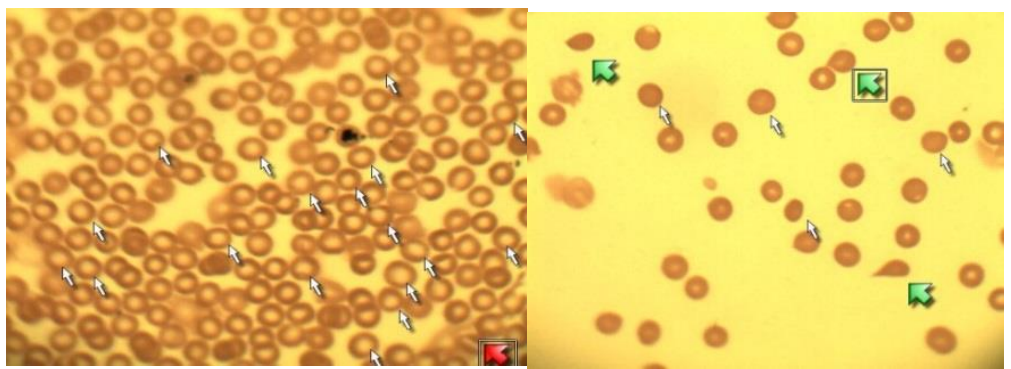

A

B

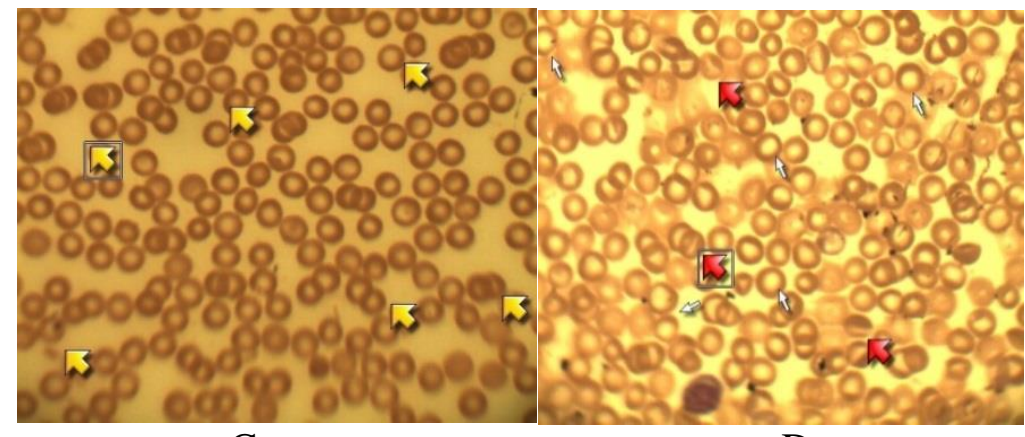

$\mathrm{C}$

$\mathrm{D}$

Figure 1: (A,B, C, D)

Leukocyte cells showed no deviation from physiological framework. Rats are animals which, in normal circumstances, have prevailing lymphocytic picture, ${ }^{(21,22)}$ what was determined by analysing the obtained results. In the group of males, a mild neutrophilia was determined when compared to the group of females. Similar studies ${ }^{(15)}$ indicate the increase in the number of lymphocytes in the peripheral blood picture of rats which were fed with the enriched bread, with Fe doses $(60 \mathrm{mg} / \mathrm{kg})$ and folic acid $(1.6 \mathrm{mg} / \mathrm{kg})$.

\section{Conclusions \& Recommendations}

The four-week diet of laboratory rats with bakery products resulted in early sideropenic hypochromic anaemia normocytic type, confirmed by lower red cell number, lower concentrations of haemoglobin as well as the presence of atypical forms of red cells (anulocytes and spherocytes). The confirmed hypochromic anaemia was probably caused by a deficiency of vitamin B2 and folic acid, as well as by deficits of vitamin B1, iron and copper.

Rats fed by bread, pastry, pasta and other confectionery products made of wheat flour, are not suitable for any type of scientific research. Researchers will then lose valuable time, financial resources, medical substances, surgical supplies and so on.

In case of usage of baked confectionery products for meals of rats intended for use as biomedical models, it is recommended to complement their meal with vitamin-mineral supplements $(\mathrm{Fe}, \mathrm{Cu}$, B9, B3, B1), with prior haematology and biochemistry blood testing.

\section{Acknowledgements}

The authors would like to express their gratitude to all technical staffs who have helped in performing the study. 


\section{References}

[1] [1] Ali Abid Abojassim, Haider Salih Jaffat, Adhraa Baqir Hassan. (2015). "EFFECTS OF GAMMA RADIATION ON SOME HEMATOLOGICAL PARAMETERS IN FEMALE RATS.” ISJ Theoretical \& Applied Science, 05(25), 101-109. http://dx.doi.org/10.15863/TAS.2015.05.25.19

[2] H.J. Hedrich. (2000). "HISTORY, STRAINS AND MODELS." In: Ed. George Krinke." THE LABORATORY RAT." Handbook of Experimentaal Animals, Academic Press, London, UK, p. 3-7.

[3] Lejla Saračević,Nedžad Gradaščević, Antonio Mihalj, Davorin Samek.(2004). "ACUTE RADIATION SYNDROME IN DOMESTIC ANIMALS.”Academic Press, ISBN 9958-599-074, COBISS.BH-ID 12759046, Sarajevo, p. 23-25.

[4] Gordana Gregurić Gračner, Damjan Gračner, Željko Pavičić. (2015). "THE BEHAVIOUR OF LABORATORY ANIMALS - MICE AND RATS.” Veterinarska Stanica, 46 (3), 197-206.

[5] Sherif EA Badr, Hanan MA, El Ghandour, Eman M Ragheb, AS Abdel Rahman. (2013). "BRAN BREAD: CHEMICAL COMPOSITION, FUNGAL LOAD, BIOLOGICAL IMPACTS AND INTERVENTION." Research Journal of Pharmaceutical, Biological and Chemical Sciences, 4 (4), 841-864.

[6] Charlotte C. Burn. (2008). "WHAT IS IT LIKE TO BE A RAT? RAT SENSORY PERCEPTION AND ITS IMPLICATIONS FOR EXPERIMENTAL DESIGN AND RAT WELFARE.” Appl. Anim. Behav. Sci. 112, 1-32.

[7] Muhamed Katica, Muhamed Kadić, Ermin Šaljić. (2003). "INCLOSURE TO RESEARCH ON THE PREVALENCE AND BIOLOGY OF COMMENSAL RODENTS AS POTENTIAL SOURCES OF THE TRANSMISSION OF DISEASE." Book of Abstract. $1^{\text {th }}$ Symposium of Agriculture, Veterinary and Forestry, Bosnia and Herzegovina.

[8] Tatijana Zemunik, Marijana Peruzović, Karmela Milković.(2000). "EXPERIMENTAL ANIMALS IN RESEARCH ON CONSE QUENCES OF UNDERNUTRITION.” In: Ed. Marko Radačić, Ivo Bašić, Damir Eljuga. "TEST MODELS IN BIOMEDICINE "Medical edition, Croatia, Zagreb, p. 115-121.

[9] Vitomir Ćupić, Dragan Kataranovski, Nikola Popović, Todor Palić. (1999). "FUNDAMENTALS OF BIOLOGY, CLINICAL PATHOLOGY AND THERAPY OF UNDOMESTICATED PETS.” Serbia, Beograd, p. $48-58$.

[10] Margi Sirois. (2005). "LABORATORY ANIMALS MEDICINE PRINCIPLES \& PROCEDURES. St. Louis”. Elsevier (Mosby), ISBN: 0-323- 01944-7.

[11] Mehmed Muminović, Indira Mujezinović, Ahmed. Smajlović, Ramiz Velić, Jasmin Omeragić.(2006). "GROWING AND THERAPY OF DISEASES OF LABORATORY ANIMALS." University textbook, Veterinary Faculty, University of Sarajevo, p. 6-7, 52.

[12] Križan Čuljak, Ruža Sabočanec. (2000). "REVIEW OF PATHOLOGY OF MICE AND RATS IN OUR CONDITIONS.” In: Ed. Marko Radačić, Ivo Bašić, Damir Eljuga.” TEST MODELS IN BIOMEDICINE.” Medical edition, Croatia, Zagreb, 159-162.

[13] Indira Mujezinović, Mehmed Muminović. (2012). "PHARMACOLOGY OF VITAMINS AND MINERALS IN LABORATORY ANIMALS." University textbook, Veterinary Faculty, University of Sarajevo, Elimta d.o.o., Sarajevo, p. 33-37, 39-43, 60-64, 104-109, 119-122.

[14] Marija Menkinoska, Icko Gjorgoski. (2011). "DETERMINATION OF PARAMETERS FROM BLOOD PICTURE OF WHITE LABORATORY RATS FED WITH ENRICHED BREAD." Journal of Hygienic Engineering and Design, UDC 612.111.11.084:664.661/.663.

[15] Marija Menkinoska,Valentina Pavlova, Icko Gjorgoski, Tatjana Blazevska. (2013). Book of Abstracts. "THE EFFECTS OF TREATMENT WITH ENRICHED BREAD ON HAEMATOLOGICAL PARAMETERS LYMPHOCYTES, MONOCYTES." $48^{\text {th }}$ Croatian $\& 8^{\text {th }}$ International Symposium on Agriculture, Book of Abstracts, $17^{\text {th }}$ to $22^{\text {nd }}$ February, 2013. 
[16] Levent Ozturk, Mustafa Atilla Yazici, Cemal Yucel, Ayfer Torun,Cemal Cekic, Ahmet Bagci, Hakan Ozkan, Hans-Joachim Braun, Zehra Sayers, Ismail Cakmaka. (2006). "CONCENTRACION AND LOCALIZATION OF ZINC DURING SEED DEVELOPMENT AND GERMINATION IN WHEAT.” Physiologia Plantarum. 128, 144-52.

[17] Rennan G. O. Arauj, Samuel M. Macedo, Maria das Graças A. Korn, Maria Fernanda Pimentel, Roy E. Bruns, Sergio L. C. Ferreira. (2008). "MINERAL COMPOSITION OF WHEAT FLOUR CONSUMED IN BRAZILIAN CITIES." Journal of the Brazilian Chemical Society, vol.19 no.5, São Paulo, On-line version ISSN 1678- 4790. http://dx.doi.org/10.1590/S010350532008000500019.

[18] Mary M. Christopher, Michelle G. Hawkins, Andrew G. Burton. (2014). "POIKILOCYTOSIS IN RABBITS: PREVALENCE, TYPE, AND ASSOCIATION WITH DISEASE.” PLoS ONE. 9(11): e112455. https://doi.org/10.1371/journal.pone.0112455

[19] Janet C. Garber. (2011). "GUIDE FOR THE CARE AND USE OF LABORATORY ANIMALS." National Research Council of the National Academic, 8th Edition, Washington, p. 4-9.

[20] B.J. Gnadt. (2006). "ETHICAL AND LEGAL PERSPECTIVES.” In: Ed. Mark Suckow, Steven Weisbroth, Craig FrankliN. "THE LABORATORY RAT." $2^{\text {nd }}$ Edition, American College of Laboratory Animal Medicine Series, Elsevier Academic London, UK, p. 54-64.

[21] B.D.Car, V.M. Eng, N. Everds, D.I Bounous. (2006). "CLINICAL PATHOLOGY OF THE RAT.” In: Ed. Mark Suckow, Steven Weisbroth, Craig Franklin. "THE LABORATORY RAT." $2^{\text {nd }}$ Edition, American College of Laboratory Animal Medicine Series, Elsevier Academic London, UK, p. 127-145.

[22] Iris Kampfmann, Natali Bauer, Sigrid Johannes, Andreas Moritz. (2012). "DIFFERENCES IN HEMATOLOGIC VARIABLES IN RATS OF THE SAME STRAIN BUT DIFFERENT ORIGIN." Vet Clin. Pathol. 41(2), 228-234. https://doi: 10.1111/j.1939-165X.2012.00427.x.

[23] Henry C. Sherman. (1942). "CHEMISTRY OF FOODS AND NUTRITION." Macmillan Company, New York, p. 58- 66.

[24] Zed Rengel, Graeme Batten, David Crowley. (1999). "AGRONOMIC APPROACHES FOR IMPROVING THE MICRONUTRIENT DENISTY IN EDIBLE PORTIONS OF FIELD CROPS." Field Crops Research. 60, 27-40.

[25] Tatjana Božić. (2012). "PATHOLOGICAL PHYSIOLOGY OF DOMESTIC ANIMALS." Text Book, $2^{\text {nd }}$ Edition, Mladost Biro d.o.o., Serbia, Belgrade, p. 47-55.

[26] B. Labar \& E Hauptmann. (1998). Hematology. Text Book, ISBN 953-0-30598-2, Croatia, Zagreb, p. 11-27.

[27] B.M. Bush. (1991)."INTERPRETATION OF LABORATORY RESULTS FOR SMALL ANIMAL CLINICIANS.” Royal Veterinary College, University of London, Blackwell Science, UK, p. 48-53.

[28] Pawan Kumar, R.K. Yadava, B. Gollen, S. Kumar, R.K. Verma, S. Yadav. (2011). "NUTRITIONAL CONTENTS AND MEDICINAL PROPERTIES OF WHEAT: A REVIEW, LIFE SCIENCES AND MEDICINE." Research, Volume, LSMR-22.

[29] John W. Harvey. (2001). "ATLAS OF VETERINARY HAEMATOLOGY.” W.B. Saunders Company, Philadephia, USA, p. 27-34.

[30] Antonio Amoroso, Filippo Rossi Fanelli. (2014). "SEMEIOTICA MEDICA E METODOLOGIA CLINICA.”, In: Ed. A. Delfino."SEMEIOTICA DEL SISTEMA EMOPOIETTICO.”, Capitolo 9, Medicina-Scienze; p. 527-530.

\footnotetext{
*Corresponding author.

E-mail address: muhamed.katica@vfs.unsa.ba
} 